Digital Press Life Sciences

Microbiology, Chemical, and Sensory Characteristics of Cocoa Powder: The Effect of Lactobacillus plantarum $\mathrm{HL}-15$

as Culture Starter and Fermentation Box Variation

Titiek Farianti Djaafar, Dhea Cynthia Monika, Tri Marwati, Priyanto Triwitono and Endang Sutriswati Rahayu

10th Asian Conference of Lactic Acid Bacteria

I Nengah Sujaya, Endang S. Rahayu, Tyas Utami (eds) 


\title{
Microbiology, Chemical, and Sensory Characteristics of Cocoa Powder: The Effect of Lactobacillus plantarum HL-15 as Culture Starter and Fermentation Box Variation
}

\author{
Titiek Farianti Djaafar ${ }^{1 *}$, Dhea Cynthia Monika ${ }^{2}$, Tri Marwati ${ }^{1}$, Priyanto Triwitono $^{2}$, and Endang \\ Sutriswati Rahayu ${ }^{2}$
}

1Postharvest Department, Assessment Institute for Agricultural Technology Yogyakarta, Indonesia

2 Food Science Department, Faculty of Agricultural Technology, Gadjah Mada University, Yogyakarta, Indonesia

*e-mail: titiekfd1212@gmail.com

\begin{abstract}
Cocoa powder is made from fermented cocoa beans which are separated from fat, grounded and sifted to produce a powder. The fermentation stage is an important stage in processing cocoa beans for chocolate flavor formation. The traditional fermentation done by farmer triggers fungal growth that can produce a toxin called mycotoxin. The use of lactic acid bacteria in cocoa beans fermentation has been known to inhibit the growth of mycotoxin-producing fungi. The addition of Lactobacillus plantarum HL 15 as a culture starter has known as an antifungal. The objective of this research is to study the effect of Lactobacillus plantarum HL 15 as culture starter and fermentation box variation on microbiology, chemical and sensory characteristics of cocoa powder. Cocoa beans fermentation was conducted by starter culture addition and without starter culture addition and then using a new fermentation box and old fermentation box. The analysis of cocoa powder was carried out include water content, $\mathrm{pH}$, fungi contamination, and sensory evaluation on color, flavor and taste of the cocoa powder. The result showed that water content ( $3.85 \%$ to $4.55 \%), \mathrm{pH}$ (4.85 to 4.95 ), and sensory evaluation is not significant differences for all treatment. The addition of Lactobacillus plantarum HL 15 as a culture starter in old and new fermentation boxes has a smaller lever of fungi contamination compare to the treatment without Lactobacillus plantarum HL 15 as culture starter.
\end{abstract}

\section{Keywords}

lactobacillus plantarum as culture starter, cocoa fermentation, fermentation box, cocoa powder

\section{Introduction}

Cocoa is one of the three largest commodities produced in Indonesia besides tea and coffee. The total area of cocoa plantations in Indonesia in 2016 reached 1,701,351 $\mathrm{m}^{2}$ with a production of 656,817 tons from community plantations, state plantations, and private plantations. This number is predicted to increase in 2017 to 688,345 tons. Cocoa productivity in Indonesia about $380 \mathrm{~kg} / \mathrm{ha}$ [1]. The high cocoa productivity to makes cocoa as one of Indonesia's export commodities.

Every region in Indonesia has the potential to develop cocoa production. The Special Region of Yogyakarta has a total area of 5,156 ha of cocoa plantations with production reaching 1,212 tons in 2015. Cocoa productivity in the Special Region of Yogyakarta reaches $235 \mathrm{~kg} / \mathrm{ha}$ and entirely belongs to community plantations [1]. This high productivity has not been matched by good postharvest handling and often has an impact on the quality diversity of the dried cocoa beans produced. The diversity of the quality of Indonesian cocoa beans is caused by several factors such as the lack of processing facilities, weak quality control at all stages of the processing of people's cocoa beans.

The dry fermented cocoa beans from small plantations still face post-harvest problems. The quality problems of Indonesian cocoa are the high level of acidity of beans followed by the weak flavor, the lack of quality consistency and unfermented beans. According to Haryadi and Suprianto [2], the cocoa beans of Indonesian farmers, especially those produced by small plantations are the lowest valued in the international market due to the low quality of the beans and dominated by unfermented beans (slaty). 
Contamination of mycotoxin-producing fungi is a concern in improving the quality of fermented cocoa beans related to the dangers of mycotoxins produced and the condition of post-harvest cocoa beans that support the growth of mycotoxin-producing fungi. The optimum temperature for aflatoxin forming by Aspergillus sp. is $5-45^{\circ} \mathrm{C}$ with minimum humidity $80 \%$ at $\mathrm{pH} 5,5-7,0$ [3,4]. This condition is easily achieved during the fermentation of cocoa beans, which shows the magnitude of potential contamination of mycotoxin-producing fungi during the fermentation process. Some types of fungi that are found to contaminate cocoa are Penicillium, Aspergillus niger, dan Aspergillus flavus [5,6,7,8]. These fungi are found in cocoa bean which during fermentation do not experience stirring [2]. Fungal contamination of permitted food products is regulated in the Indonesian National Standard (SNI).

Fermentation is an important step in processing cocoa beans that determine the quality of cocoa beans. In the fermentation process, the formation of cocoa flavor precursor compounds by microbes such as yeast, lactic acid bacteria, and acetic acid bacteria by changing the substrate into ethanol, lactic acid, and acetic acid. Fermentation plays an important role in determining the final quality of dried cocoa beans. At the time of fermentation, there is the involvement of lactic acid bacteria (LAB) which have the ability to produce lactic acid, which can inhibit the growth of fungi $[9,10,11,12]$.

In the cocoa bean fermentation, LAB has proven role as an antifungal. Many studies have been done to determine the ability of LAB in inhibiting the growth of fungi producing toxin (ochratoxin) during the cocoa beans fermentation. The application of LAB in cocoa bean fermentation is the biological control of OTA-producing fungi. According to the identification of LAB as Lactobacillus plantarum B4496, Lactobacillus brevis 207 and Lactobacillus sanfranciscensis BB12 showed interesting in vitro broad antifungal activities towards the three ochratoxin-producing fungi (Aspergillus carbonarius, Aspergillus niger and Aspergillus ochraceus) with inhibition percentages ranging from $15 \%$ to $66.7 \%$ [13]. According to Deepthi et al [14]., Lactobacillus has anti-fungal ability. The metabolic product of LAB causes an acid condition that inhibits germination and hypha formation from mold. Anti-fungal compounds such as phenillactic acid (PLA) and 4-hydroxyphenillactic acid was found in Lactobacillus plantarum [15]. Marwati et al [16,17] said that Lactobacillus plantarum HL15 has potential as antifungal. The use of Lactobacillus plantarum HL15 is expected to reduce fungi contamination during the fermentation of cocoa beans.

The addition of Lactobacillus plantarum HL15 in the cocoa beans fermentation, it certainly affects the chemical, microbiology and sensory character of the cocoa beans which will be processed into cocoa powder. Therefore, the objective of this study is to find out the effect of adding Lactobacillus plantarum HL15 as a starter culture and variation of fermentation box on the chemical, microbiology and sensory characteristic of cocoa powder.

\section{Material and Method}

\subsection{Material and Equipments}

The materials used in this research were cocoa beans that had been fermented with Lactobacillus plantarum HL15 as starter and cocoa beans fermented without a starter. So in this study used four type of cocoa beans, namely (1) fermented cocoa beans without a starter on the old box, (2) fermented cocoa beans without a starter on the new box, (3) fermented cocoa beans with a starter on the old box and (4) fermented cocoa beans with a starter on the new box. Fermented cocoa beans were obtained from Ngudi Raharjo II farmers group, Gunung Kidul, Yogyakarta. In the process of cocoa powder, the materials used are cocoa cake, vanilla, sugar, corn starch and baking soda.

In the sensory evaluation, the materials used were aqua dest, cocoa powder from various treatments and sugar. In the microbial contamination test, used aqua dest, chloramphenicol, Buffer Pepton Water (BPW), DG18 and Peptone Dextrose Agar.

Cocoa powder process was conducted using steamer, roaster, rotary cutter, blower and separator for winnowing process, castor, hydraulic presser, grinder for cocoa powder process, sieve, alkalizing machine, refrigerator or cooler.

Water content analysis used dedicator, oven, analytic scale, spatulas and weigh bottle. pH level was determined used $\mathrm{pH}$ meter. The tools used in the sensory evaluation are glass, pans, stoves, trays and measuring spoon. In microbial contamination testing the tools used were bunsen, Petri dishes, Erlenmeyer, analytical scales, micropipette, autoclaves, incubators, filters, spatulas, and analytic scales. 


\subsection{Method}

This study was conducted in two stages. The first stage was the cocoa powder processing conducted in Agro Techno Park, Gunung Kidul. The second stage was the quality analysis of cocoa powder. Chemical, microbiology, and sensory evaluation were conducted based on the Indonesian National Standard [18] for cocoa powder.

\subsubsection{Cocoa powder Processing}

Cocoa powder processing was conducted in Agro Techno Park, Gunung Kidul based on the method presented by Copetti et al [19]. The making of cocoa powder begins steaming fermented cocoa beans at $100{ }^{\circ} \mathrm{C}$ for 30 minutes. And then roasting at $120^{\circ} \mathrm{C}$ for 30 minutes. Separation of seed coat was conducted using the separator is equipped with a blower. The nib, which is obtained, is put into a caster to produce chocolate paste. Furthermore, the chocolate paste is pressed using a hydraulic press for about 15 minutes to separate the cocoa butter and chocolate cake. Chocolate cake is crushed and put into refrigerator before milling. After grinding, sifting is done (200 mesh). The sifting process was carried out several times to obtain maximum results. Finally, the alkalization process was carried out to produce cocoa powder.

\subsubsection{Water content assay}

The water content of cocoa powder was determined by thermogravimetry [20].

\subsection{3 pH assay}

The measurement of $\mathrm{pH}$ using $\mathrm{pH}$ meter [18].

\subsubsection{Microbial contamination assay}

Microbial contamination test with direct plating method on DG 18 media to determine the type of mold and dilution method on PDA media to count the number of mold colonies per gram sample [21,22]. A direct plating test is done by sowing a number of cocoa powder samples on the media so that DG18 is evenly distributed on Petri dishes. The Petri dish is then incubated at room temperature for 5 days. After 5 days, observations of fungi grew and were identified based on their appearance and color characteristics.

The dilution method was carried out by dilution Buffer Pepton Water with dilution sequent 10-2, 103 and $10^{-4}$. Then pouring the media PDA as much as $15 \mathrm{ml}$ into a Petri dish is then incubated at room temperature for 5 days. Calculation of the colony formed using the rules of colony calculation in accordance with PPOMN 2006.

\subsubsection{Sensory assay}

Sensory testing was carried out using 40 panelists using the hedonic method and difference scoring test [18]. Samples are presented in the form of powder and chocolate drinks. Panelists conducted an assessment in no specified order using a scale of 1 to 7 . Scale 1 shows the attribute with the weakest value and scale 7 shows the attribute with the strongest value for Difference Scoring Test. Sensory testing with the Difference Scoring Test is an assessment of the color, aroma, and flavor attributes of cocoa powder and chocolate drinks. As for the Hedonic Test, scale 1 shows the most disliked sample and scale 7 shows the most liked sample.

\section{Result and Discussion}

\subsection{Water Content of Cocoa Powder}

Overall cocoa powder has a moisture content in accordance with SNI 3747: 2009 is less than 5\% by weight and not significantly different between treatments. The water content of cocoa powder as shown in Fig 1. Cocoa powder from cocoa beans fermented with a starter in the old fermentation box has a water content of $4.19 \%$. Cocoa powder from fermented cocoa beans without a starter in the old fermentation box has a moisture content of 3.85\%. Cocoa powder produce from fermented cocoa beans with a starter in a new fermentation box has a water content of $4.55 \%$. Whereas the cocoa powder 
produce from fermented cocoa benas without a starter in the new fermentation box has a moisture content of $4.09 \%$.

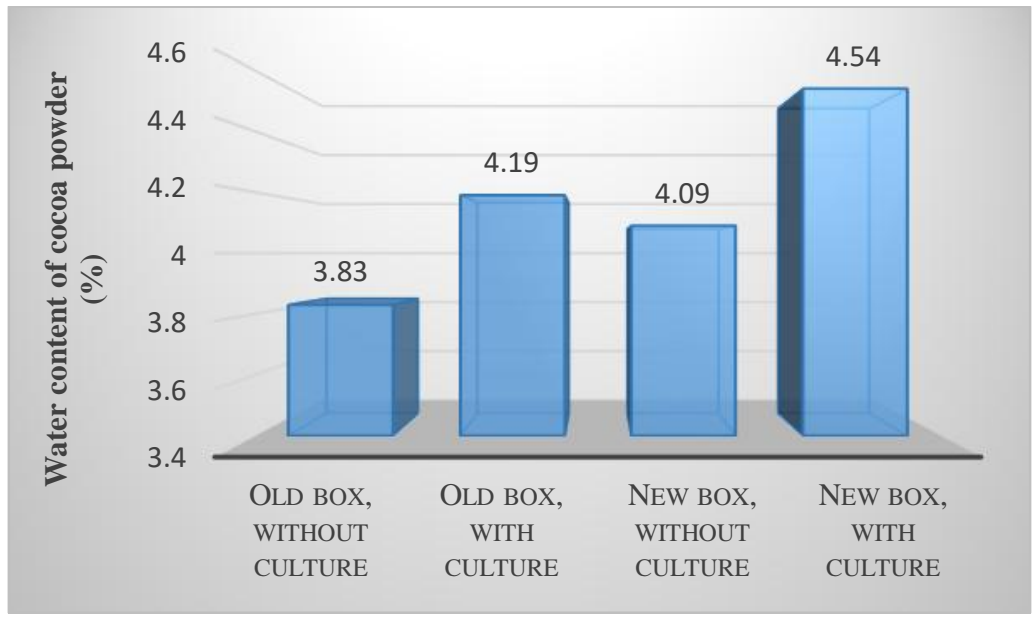

Fig 1. Water content of cocoa powder

Moisture content in cocoa beans after fermentation is reduced by drying. The water content of fermented cocoa beans was $60 \%$ lowered to less than $7 \%$ to $8 \%$ through the drying process [23]. According to Putri [24], the moisture content of fermented cocoa beans with L. plantarum HL 15 as starter is $6.52 \%$. In the roasting process, the moisture content decrease to less than $3 \%$. The water content of cocoa powder is determined by the processing, namely drying cocoa beans and roasting where the heat can evaporate the free water contained in cocoa beans. During the processing of cocoa powder, absorption of environmental moisture can occur by the material so that the water content increases.

\section{$3.2 \mathrm{pH}$ of Cocoa Powder}

One important factor determining the high consumer acceptance of chocolate powder flavor is the acidity attribute. The acidity of the cocoa powder is influenced by the $\mathrm{pH}$ value. The $\mathrm{pH}$ value of the cocoa beans to be processed into cocoa powder changes due to the evaporation of volatile organic acids and alkalization [19]. The $\mathrm{pH}$ values of the cocoa cake and the cocoa powder are also different. Cocoa powder has a higher $\mathrm{pH}$ value because it has been alkalized. The $\mathrm{pH}$ value of cocoa cake and cocoa powder can be seen in Fig 2 and Fig 3.

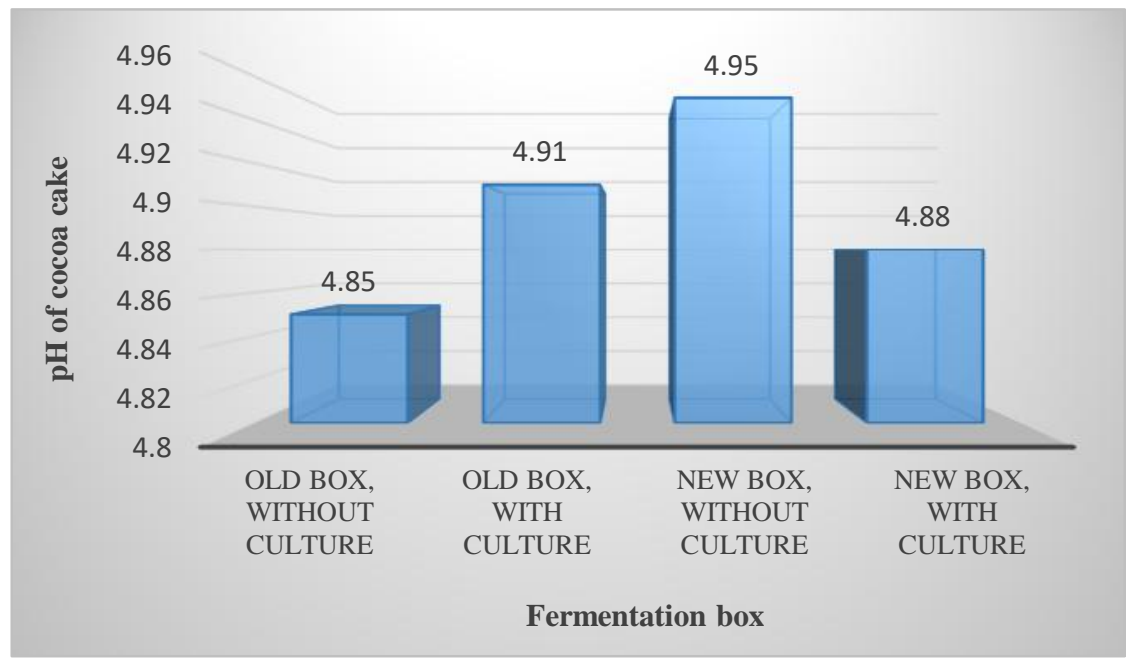

Fig 2. $\mathrm{pH}$ value of cocoa cake 


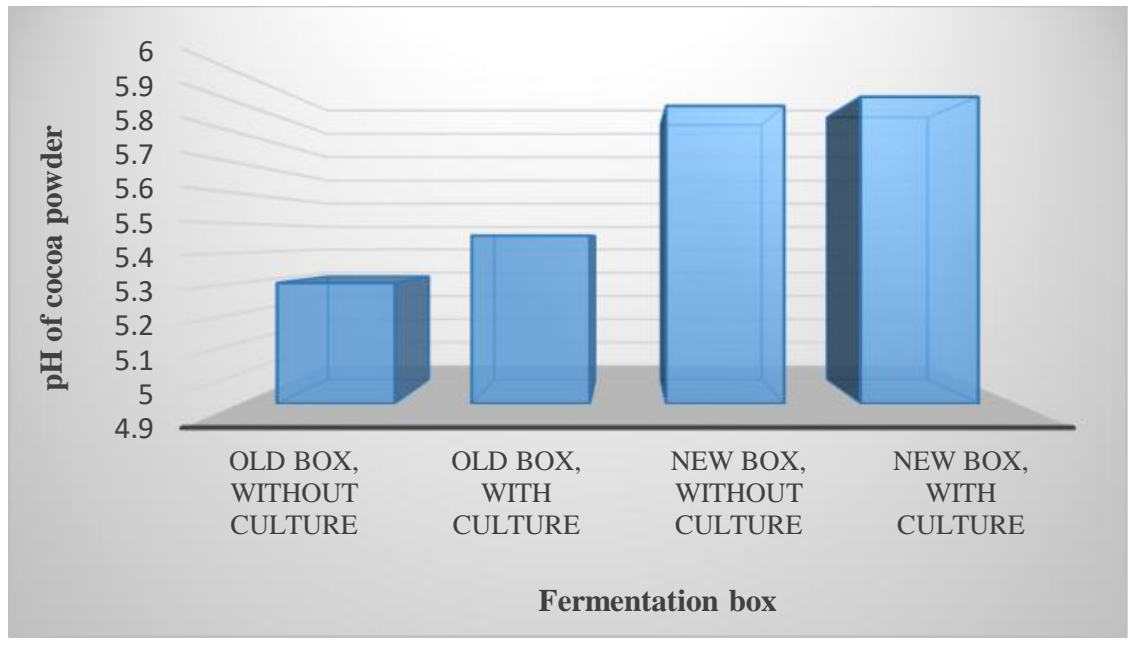

Fig 3. $\mathrm{pH}$ value of cocoa powder

The pH levels successively from highest to lowest in cocoa cake are fermented cocoa beans without starter in a new fermentation box (4.95), fermented cocoa beans with a starter in the old fermentation box (4.91), fermented cocoa beans with starter in a new fermentation box (4.88), and fermented cocoa beans without a starter in the old fermentation box (4.85). In cocoa meal it is known that the lowest pH is cocoa cake from fermented cocoa beans without a starter in the old fermentation box (4.85). In cocoa meal it is known that the lowest $\mathrm{pH}$ is cocoa cake from fermented cocoa beans without a starter in the old fermentation box (4.85). The pH levels successively from highest to lowest in cocoa powder are fermented cocoa beans without a starter in the old fermentation box (6.3), fermented cocoa beans with a starter in a new fermentation box (5.93), fermented cocoa beans without starter in a new fermentation box (5.89), and cocoa beans fermented with a starter in the old fermentation box (5.46). Whereas in cocoa powder it is known that the lowest $\mathrm{pH}$ is cocoa powder from cocoa beans fermented with a starter in the old fermentation box (5.46).

The $\mathrm{pH}$ value of cocoa powder is influenced by the $\mathrm{pH}$ value of fermented cocoa beans. The low $\mathrm{pH}$ value in cocoa beans is caused by the migration of acetic acid and lactic acid during fermentation and decreases the $\mathrm{pH}$ in the beans from 6.5 to 4.5 [25]. According to Ho et al [26], acetic acid has more effect on decreasing pH than lactic acid. The 4.75 to $5.19 \mathrm{pH}$ value shows that fermentation succeeded [25]. At the time of roasting, there is the volatilization of volatile organic acids which allows a decrease in acid concentration and an increase in $\mathrm{pH}$ [21]. However, the increase in $\mathrm{pH}$ value during the processing is not too significant so that the $\mathrm{pH}$ value on the cocoa cake and cocoa beans do not differ. The $\mathrm{pH}$ value on the cocoa cake can be used as a parameter of process success. Based on this, it can be stated that the fermentation of cocoa beans used in processing cocoa powder has been done well. The difference in $\mathrm{pH}$ between treatments on cocoa cake showed no significant difference.

In the processing of cocoa powder from the cocoa cake, the cocoa cake is crushed, milled, sifted and alkalised to produce cocoa powder in accordance with the standards. One process that affects the final pH of cocoa powder is alkalization. During the alkalization the addition of baking soda, vanillin, corn starch and sugar. The main objectives of the alkalization process are to reduce acidity, increase the solubility of chocolate powder, and intensify the aroma of chocolate [27,19]. After alkalization, the overall $\mathrm{pH}$ of the four treatments increased (Fig 3). The difference in $\mathrm{pH}$ of the four treatments did not show a significant difference.

\subsection{Sensory Attribute}

\subsubsection{Difference Scoring Test}

\section{a. Brown intensity color}

The color of cocoa powder is in accordance with SNI 3747: 2009 cocoa powder. The brown color of the cocoa powder comes from the oxidation of polyphenols by oxygen and polyphenol oxidases to produce quinones which give a brown appearance [2]. This can occur because of the migration of acetic acid into cells causes a decrease in internal $\mathrm{pH}$ and rupture of cell membranes. Polyphenols also migrate out into 
the epidermis and undergo oxidation. The brown color formed shows the success of the fermentation and drying process [28].

The intensity of the brown color of the cocoa powder from fermented cocoa beans with a starter in the old fermentation box was 4.33. Cocoa powder from fermented cocoa beans without a starter in the old fermentation box is 4.98. Cocoa powder from fermented cocoa beans with a starter in a new fermentation box is 4.70. Cocoa powder from fermented cocoa beans without a starter in the new fermentation box is 4.95. Cocoa powder with fermented beans in the old box with a starter has a lower color intensity than fermented beans in the old box without a starter. The same thing happened in cocoa powder with fermented cocoa beans in a new fermentation box with a starter having a lower color intensity than fermented cocoa beans in a new box without a starter (Fig 4). However, the difference in the overall color intensity of the treatment was not significant. This can be caused by differences in panelist sensitivity.

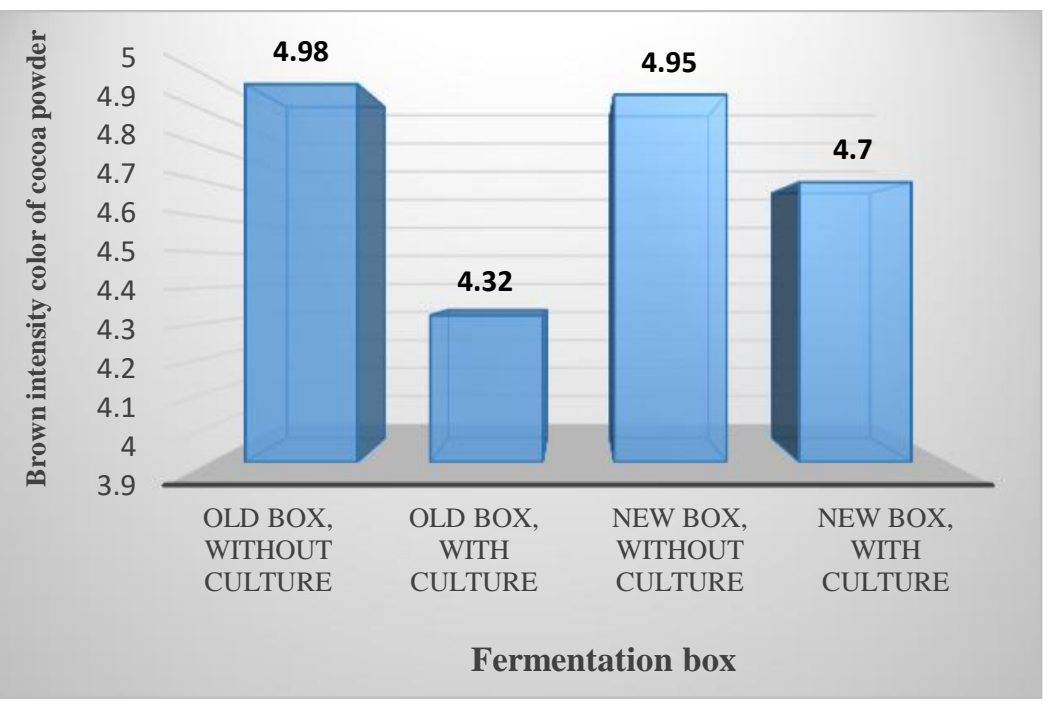

Fig 4. Brown intensity color of cocoa powder

\section{b. The specific aroma of cocoa powder}

The results are in accordance with the SNI for cocoa powder which is a distinctive aroma of cocoa and free from foreign odors. The typical chocolate aroma value for cocoa powder from fermented cocoa beans with a starter in the old fermentation box is 4.7. Chocolate powder from fermented cocoa beans without a starter in the old fermentation box is 4.85. The cocoa powder from fermented cocoa beans with a starter in a new fermentation box is 4.65. The cocoa powder from fermented cocoa beans without a starter in the new fermentation box is 4.88 (Fig 5). The intensity of the characteristic aroma of chocolate for all treatments did not show a significant difference.

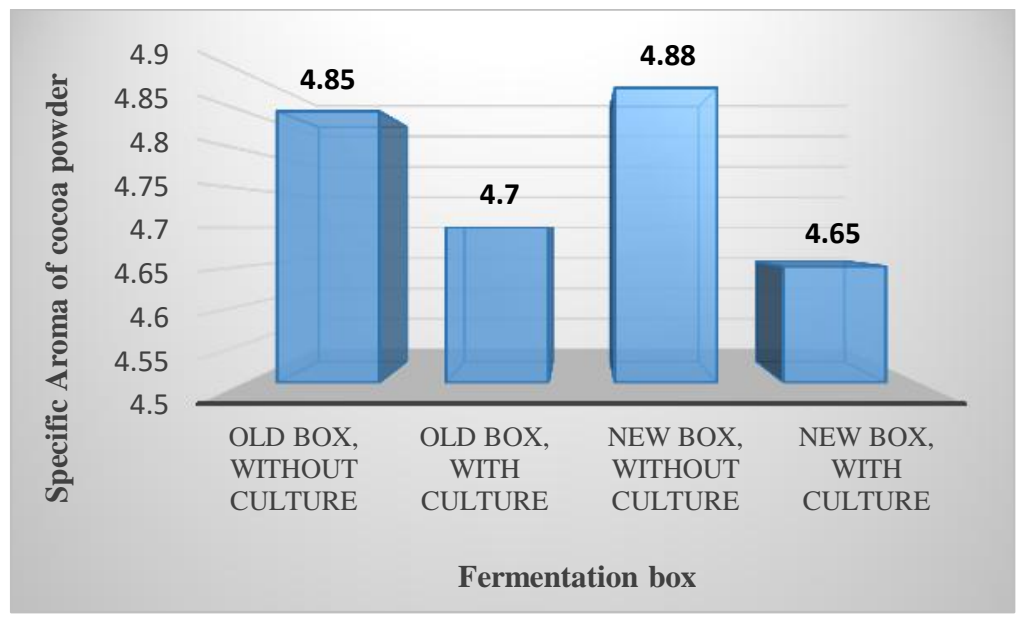

Fig 5. Specific aroma of cocoa powder 
The formation of a special aroma chocolate precursor occurs during fermentation. Protein fractions in cocoa (albumin and globulin) are converted to hydrophilic and hydrophobic peptides and amino acids by aspartic endoprotease and carboxypeptidase activated by organic acids during fermentation [29]. Amino acids and oligopeptides form essential precursors for the formation of chocolate aromas during roasting by the Maillard reaction [28].

\section{c. Bitterness flavor}

The formation of bitter flavor occurs during fermentation. Damage to cell membranes due to an increase in internal $\mathrm{pH}$ after the entry of acetic acid and lactic acid causes the mixing of various enzymatic reactions [28, 30]. Polyphenol and methylxanthine to be responsible for bitter flavor formation [31,32]. The existence of these compounds is determined by the type of cocoa, climatic conditions, fermentation, drying and processing in the industry [25].

The intensity of the bitter chocolate powder flavor from fermented cocoa beans with a starter in the old fermentation box is worth 4.15; cocoa powder from fermented cocoa beans without a starter in the old fermentation box was 3.43; cocoa powder from fermented cocoa beans with starter in the new fermentation box is 4.63 and cocoa powder from fermented cocoa beans without starter in the new fermentation box is 3.8. Based on these results it is known that the cocoa powder from cocoa beans fermented with a starter in the old and new fermentation boxes has a bitter flavor that is stronger than the cocoa powder from the fermented beans without the starter in the old and new fermentation boxes, but the difference is not significant (Fig 6).

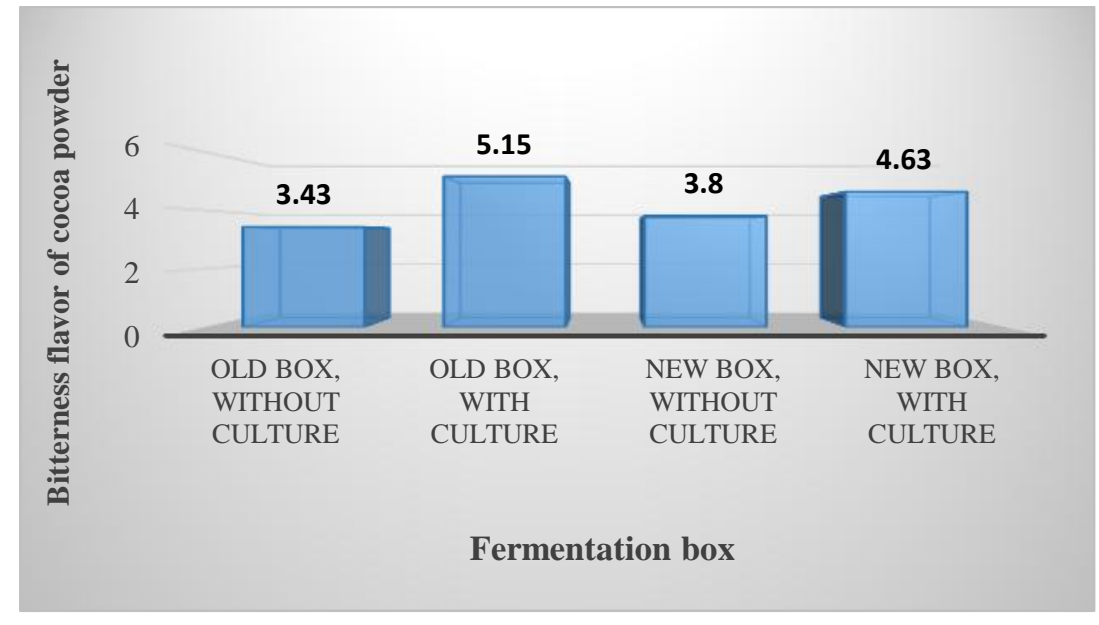

Fig 6. Bitterness flavor of cocoa bean

\section{d. Acidity flavor of cocoa bean}

The results of acidity flavor intensity showed that all four treatments had in accordance with the SNI 3747:2009. The acidic flavor of cocoa becomes from organic acid compound forming during fermentation [23]. The acid enters the seed cotyledons and decreases the internal $\mathrm{pH}$ [28]. The addition of Lactobacillus plantarum as a starter provides suitable conditions for better growth of acetic acid bacteria [2]. This triggers the growth of higher acetic acid bacteria to produce more acetic acid. The more acetic acid produced, the lower the $\mathrm{pH}$ will be because more acetic acid migrates into the seeds.

The intensity of the acidity flavor for cocoa powder from fermented cocoa beans with a starter in the old fermentation box was 3.48; cocoa powder from fermented cocoa beans without a starter in the old fermentation box was 2.85; the cocoa powder from fermented cocoa beans with starter in the new fermentation box is 3.4 and the cocoa powder from fermented cocoa beans without starter in the new fermentation box is 3.03 (Fig 7). Thus, the cocoa powder from cocoa beans fermented with the starter in the old and new fermentation boxes has a stronger sour flavor than the cocoa powder from fermented cocoa beans without starter in the old and new fermentation boxes, but the difference is not significant. 


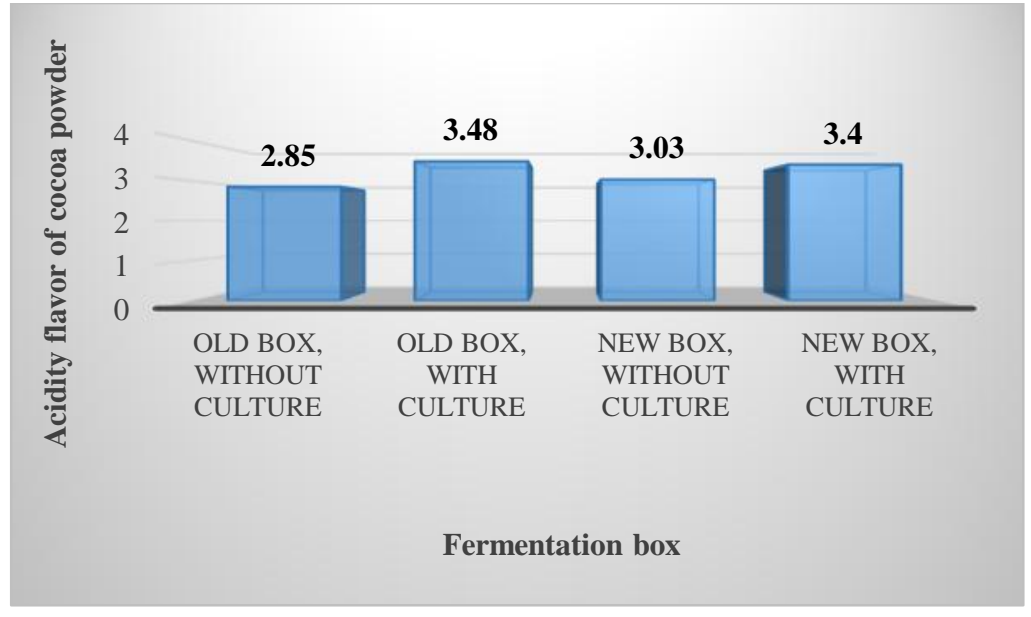

Fig 7. Acidity flavor of cocoa powder

\subsubsection{Hedonic Test}

The results showed that the overall preferred value of cocoa powder from fermented cocoa beans without starter in the old fermentation box was 4.88; cocoa powder from fermented cocoa beans with a starter in a new fermentation box is 4.8; cocoa powder from fermented cocoa beans without starter in the new fermentation box is 4.55 and chocolate powder from fermented cocoa beans with starter in the old fermentation box is 4.38. Chocolate powder from fermented cocoa beans without starter in the old fermentation box has the highest overall preference value (4.88) with the lowest acidity value (2.85), the lowest bitterness value (3.43), the highest intensity of brown color (4.98) and the distinctive aroma of high chocolate (4.85)

Cocoa powder from fermented cocoa beans with the starter in the old fermentation box has the lowest overall preference value (4.38) with the highest acidity value (3.48), the second-highest bitterness value $(4.15)$, the lowest brown color intensity $(4,325)$ and the second-lowest typical chocolate aroma (4.7). The overall sensory testing assessment is shown in Fig 8. Overall, however, there was no significant difference in the preference scores for all treatments.

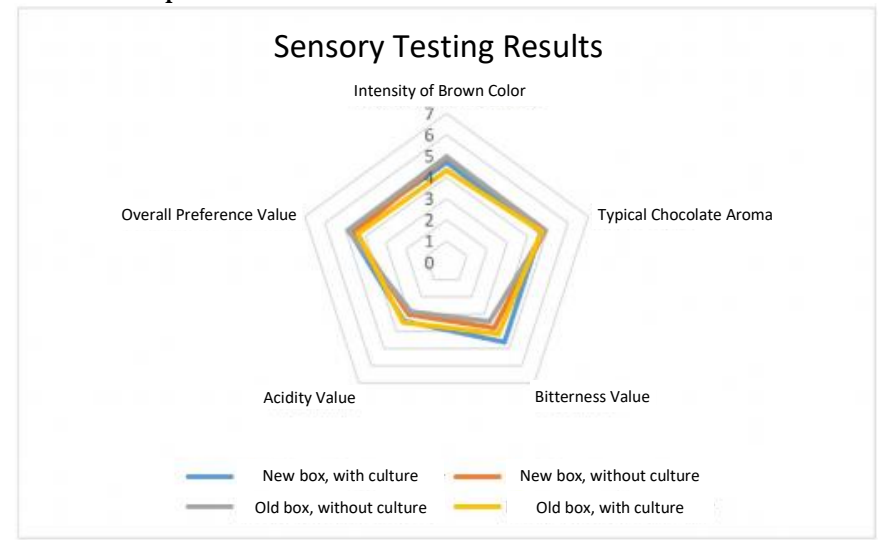

Fig 8. Hedonic value of cocoa powder

\subsection{Identification of microbial contamination of cocoa powder by direct plating method}

Based on the results, cocoa powder from fermented cocoa beans with a starter in a fermentation box, yeast and fungi were found in the form of Eurotium (Fig 9). In the cocoa powder from fermented cocoa beans without a starter in the fermentation box, new yeasts and fungi have not been identified (Fig 10). In the cocoa powder from fermented cocoa beans with a starter in the old fermentation box, yeast and fungi were found, namely Eurotium (Fig 11). In the cocoa powder from fermented cocoa beans without a starter in the old fermentation box, yeast and fungi were found, namely Eurotium (Fig 12). 

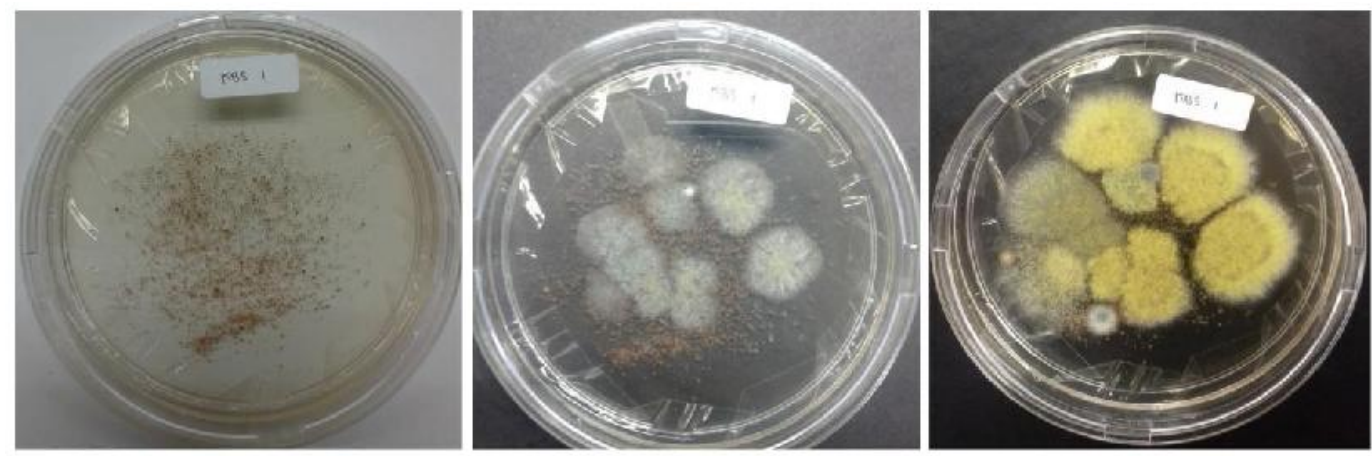

Fig 9. Cocoa powder with starter; new box; direct plating; 1.3, and 5 days incubation
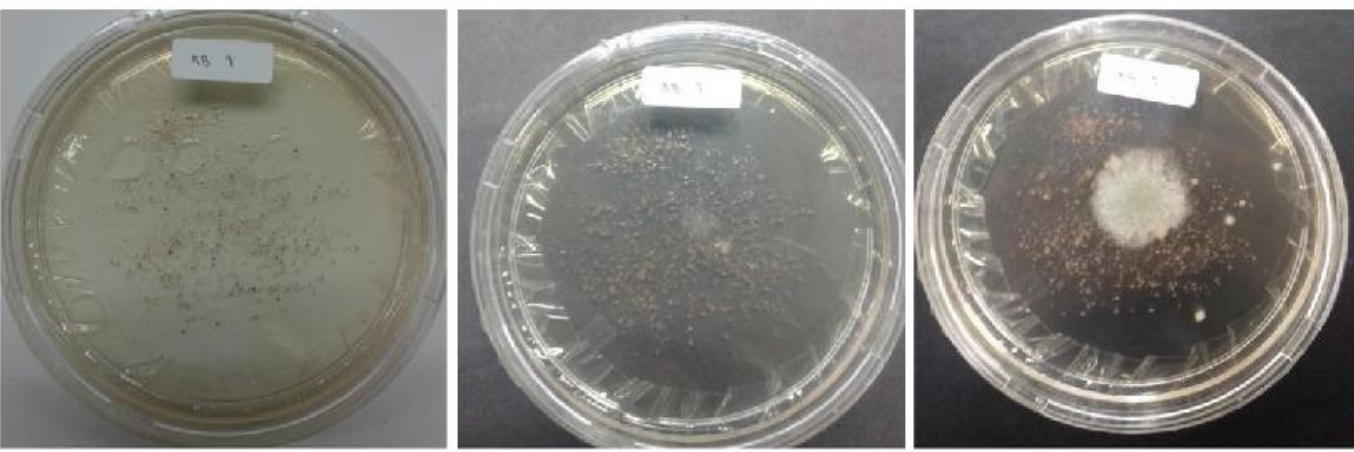

Fig 10. Cocoa powder without starter; new box; direct plating; 1.3, and 5 days incubation
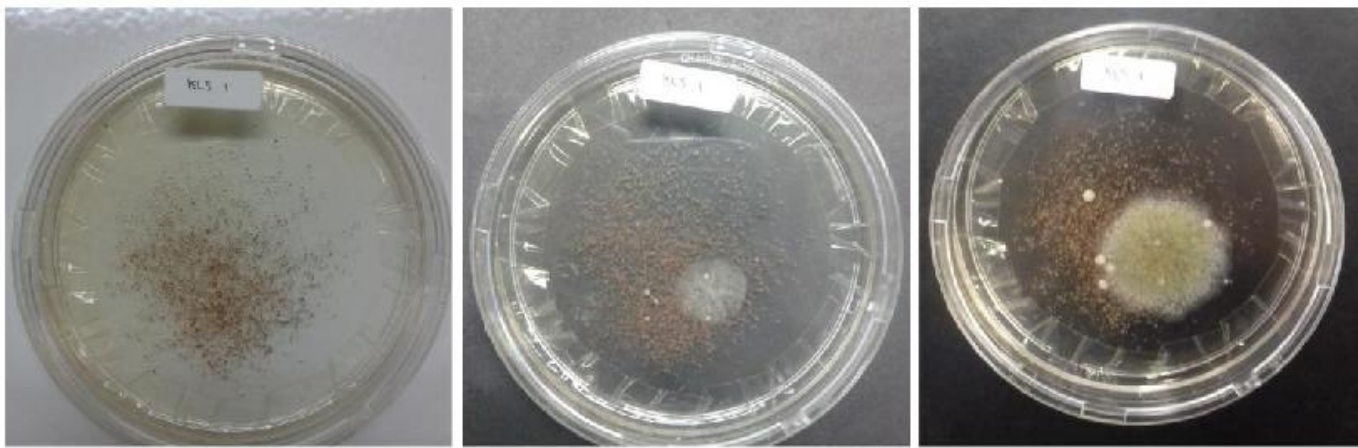

Fig 11. Cocoa powder with starter; old box; direct plating; 1.3, and 5 days incubation
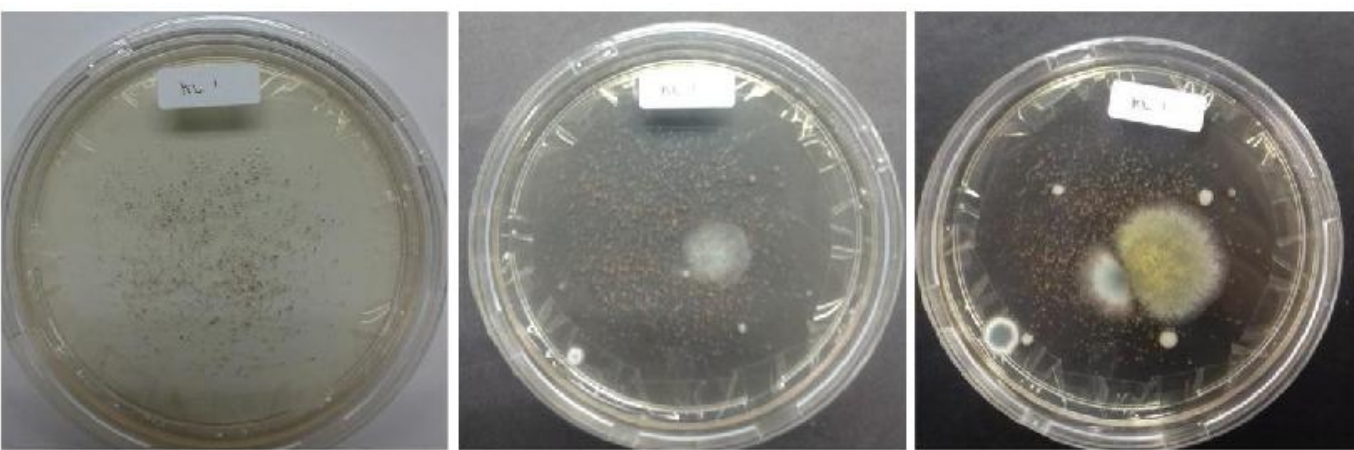

Fig 12. Cocoa powder without starter; direct plating; 1.3, and 5 days incubation

The type of fungi that are found are not fungi that can produce mycotoxins. Eurotium is a fungus that can grow during storage. Chocolate powder products contaminated with this fungus can be caused by the storage conditions of cocoa beans before they are processed into cocoa powder. The dried cocoa beans used have been stored at room temperature for 4 months (July-October 2017) with vacuum packaging. Storage is carried out at room temperature $\left(25^{\circ} \mathrm{C}-34^{\circ} \mathrm{C}\right)$ with $80-85 \%$ humidity. According to Karisma [33], fermentation of cocoa beans with starter Lactobacillus plantarum HL15 as a starter 
culture produces cocoa beans that are free fungal contamination. This shows that fermentation with Lactobacillus plantarum HL15 and good drying already suppresses the growth of fungi. Thus, fungal contamination of the final product is caused by the storage conditions of the cocoa beans before processing and fungi from the environment.

\subsection{Identification of Microbial Contamination of cocoa powder by dilution method}

Fungi contamination in cocoa powder from fermented cocoa beans with a starter in a new fermentation box is $1.5 \times 10^{2}$ colonies per gram. Cocoa powder from fermented cocoa beans without a starter in a new fermentation box is $5.5 \times 10^{2}$ colonies per gram. Fungi contamination in cocoa powder from fermented cocoa beans with a starter in an old fermentation box is $1.5 \times 10^{2}$ colonies per gram. While the cocoa powder from fermented cocoa beans without a starter in the old fermentation box is $7.0 \times 10^{2}$ colonies per gram. SNI 3747:2009 suggested that fungi and yeast contamination are allowed 1.0x10 ${ }^{2}$ colonies per gram or about 50 colonies for fungi or yeast only. Based on these results it is concluded that fungi and yeast contamination on all treatments are nothing meets the standard. From these results, it is also known that the fungal colonies on cocoa powder from fermented cocoa beans with a starter in the old and new fermentation boxes have the same value of $1.5 \times 10^{2}$ colonies per gram and lower than the colonies formed in cocoa powder from fermented cocoa beans without a starter on the old or new fermentation box.

This proves that the addition of a starter can inhibit the growth of fungi in cocoa powder products. Lactobacillus plantarum is known to have a good ability in producing anti-fungal metabolites [34]. There are two ways to systematically inhibit mold growth by Lactobacillus plantarum. The direct way is by becoming a mold competitor in obtaining a substrate or indirect way by producing the results of metabolites that are antagonistic to mold growth. Lactic acid, acetic acid and phenylacetic acid produced during the fermentation of cocoa beans are organic acids that have the most important role in inhibiting mold growth [35].

\section{Conclusion}

Based on the research that has been done, it can be concluded that the water content of cocoa powder from fermented cocoa beans with or without the addition of a starter in the old box or new box is in accordance with SNI 3747: 2009 Cocoa Powder which is less than 5\% by weight. The addition of a starter or a variation of the fermentation box did not affect the water content of the chocolate powder. Likewise, the $\mathrm{pH}$ of cake and cocoa powder did not differ significantly in all treatments.

The cocoa powder produced from the four sensory treatments according to SNI 3747: 2009 chocolate powder is good for the color of aroma and flavor. Overall, the four chocolate powder treatments did not show differences in terms of sensory.

The fungus that contaminates cocoa powder is Eurotium sp. It was found that the limit of fungi contamination of the four treatments did not meet SNI 3747: 2009 cocoa powder. Cocoa powder from cocoa beans fermented with a starter in both old and new fermentation boxes has a lower number of fungi colonies than cocoa beans with the addition of a starter which is $1.5 \times 10^{2}$ colonies per gram. Overall, it can be concluded that the addition of the starter and fermentation box did not have a significant effect on the chemical and sensory characteristics of cocoa powder. However, the treatment of adding a starter can reduce mold contamination compared to the treatment without adding a starter.

Further research needs to be done by combining the application of GAP and GMP to produce quality cocoa powder without contamination of mycotoxin-producing fungi.

Acknowledgments: The research was financially supported by the Indonesian Agency for Agricultural Research and Development (IAARD) through Collaborative Research, Assessment and Development of Strategic Agriculture Project.

\section{References}

1. Direktorat Jenderal Perkebunan. Statistik Perkebunan Indonesia: Kakao 2015-2017. Kementrian Pertanian. 2016. 
2. Haryadi and Supriyanto.: The Chocolate Technology. Yogyakarta: UGM Press. (2012). (in Indonesian).

3. Yunus, A. W., Razzazi-Fazeli, A., \& Bohm, J.: Aflatoxin B1 in affecting broiler's performance, immunity, and gastrointestinal tract: A review of history and contemporary issues. Journal of Toxins. 3, 566-590 (2011).

4. Purnamasari, L., Noviandi, C. T., \& Agus, A.: Kajian produksi aflatoksin B1 kasar dari isolate kapang Aspergillus flavus lokal pada media jagung dan jagung+kacang tanah. Buletin Peternakan. 40(2), 133-137 (2016).

5. Copetti, M. V., Iamanaka, B.T., Mororó, R. C., Pereira, J. L., Frisvad, J. C., \& Taniwaki, M. H.: The effect of cocoa fermentation and weak organic acids on growth and ochratoxin A production by Aspergillus species. International Journal of Food Microbiology. 155, 158-164 (2012). doi:10.1016/j.ijfoodmicro.2012.01.026.

6. Copetti, M. V., Iamanaka, B. T., Nester, M. A., Efraim, P., \& Taniwaki, M. H.: Occurrence of ochratoxin A in cocoa by-products and determination of its reduction during chocolate manufacture. Food Chemistry. 136, 100-104 (2013).

7. Nugroho, A. D., Setyabudi, F. M. C. S., Salleh, B., \& Rahayu, E. S.: Ochratoxigenic black Aspergilli isolated from dried agricultural products in Yogyakarta, Indonesia. Journal of Food Science and Engineering. 3, 472-480 (2013).

8. Apriyanto, Sutardi, M., Supriyanto \& Harmayani, E.: Study on effect of fermentation to the quality parameter of cocoa bean in Indonesia. Asian Journal Dairy \& Food Research. 35(2), 160-163 (2016).

9. Jespersen L., Nielsen, D. S., Hønholt, S., \& Jakobsen, M.: Occurrence and diversity of yeasts involved in fermentation of West African cocoa beans. FEMS Yeast Research. 5(4-5), 441-453 (2005).

10. Nielsen, D. S., Teniola, O. D., Ban-Koffi, L., Owusu, M., Anderson, T. S., \& Holzapfel, W. H.: The microbiology of Ghanaian cocoa fermentations analysed using culture-dependent and cultureindependent methods. International Journal of Food Microbiology. 11(2), 168-186 (2007).

11. De Vuyst, L., Lefeber, T., Papalexandratou, Z., \& Camu, N.: The functional role of lactic acid bacteria in cocoa bean fermentation. In Biotechnology of Lactic Acid Bacteria: Novel Applications ed. Mozzi, F., Raya, R.R. and Vignolo, G.M. pp. 301-326. Ames: Wiley-Blackwell (2010). doi:10.1002/9781118868386

12. Lefeber, T., Gobert, W., Vrancken, G., Camu, N., \& L De Vuyst.: Dynamics and species diversity of communities of lactic acid bacteria and acetic acid bacteria during spontaneous cocoa bean fermentation in vessels. Food Microbiology. 28, 457-464 (2011).

13. Ngang, J. J. E., Yadang, G., Kamdem, S. L. S., Ch.P Kouebou, Sandrine, A., Kougan, D. L. T., Tsoungui, A., \& Etoa, F. X.: Antifungal properties of selected lactic acid bacteria and application in the biological control of ochratoxin A producing fungi during cocoa fermentation. Biocontrol Science and Technology. 25(3), 245-259 (2015).

14. Deepthi BV, Poornachandra Rao K, Chennapa G, Naik MK, Chandrashekara KT, Sreenivasa MY. 2016. Antifungal Attributes of Lactobacillus plantarum MYS6 against Fumonisin Producing Fusarium proliferatum Associated with Poultry Feeds. PLoS ONE 11(6).

15. Lavermicocca P., et al. 2013. Antifungal activity of phenyllactic acid against molds isolated from bakery products. Appl Environ Microbiol 69 634-40.

16. Marwati, T., Khusna, R. N. B., Djaafar, T. F., \& Rahayu, E. S.: Inhibition growth of mycotoxin producing fungi by lactic acid bacteria isolated from fermented cocoa bean (Theobroma cocoa L.) in Indonesia. Proceeding of The $15^{\text {th }}$ ASEAN Conference on Food Science and Technology, November 14-17, 2017 Ho Chi Minh City, Vietnam.

17. Marwati, T., Lamadoken, I. P. P., Djaafar, T. F., Utami. T., \& Rahayu, E. S.: Production of dried Lactobacillus plantarum HL-15 culture for inhibition growth of mycotoxin producing fungi. Journal of Agricultural Science and Technology B. 8, 396-403 (2018). doi 10.17265/21616264/2018.06.007.

18. SNI 3747:2009. Kakao Bubuk. Badan Standardisasi Nasional Indonesia. 2009.

19. Copetti, M., Pitt, J. I., Lamanaka. B. T., \& Taniwaki, M.H.: Fungi and Mycotoxins in Cocoa: From Farm to Chocolate. International Journal of Food Microbiology. 178, 13-20 (2014). doi:10.1016/j.ijfoodmicro.2014.02.023.

20. Association of Official Analytical Chemists (AOAC). Official Method of Analysis of AOAC International. 18th ed. Gathersburg, MD, USA Official Methods. 2005.

21. Samson, R. A., Noonim, P., Meijer, M., Houbraken, J., Frisvad, J. C., \& Varga, J.: Diagnostic tools to identify black aspergilli. Stud Mycol. 59, 129-145 (2007). 
22. Rahayu, E. S., Sarjono, \& Samson, R. A.: Jamur Benang (Mold) pada Bahan Pangan. Penerbit Kanisius, Yogyakarta. (2013).

23. Afoakwa, E. O., Paterson, A., Fowler, M., \& Vieira, J.: Factors Influencing Rheological and Textural Qualities in Chocolate. Trend in Food Science and Technology. 18(6), 290-298 (2007). doi:10.1016/j.foodeng.2007.11.025

24. Putri, L. M.: Pengaruh kemasan vakum dan non vakum pada penyimpanan suhu dingin $\left(5-6{ }^{\circ} \mathrm{C}\right)$ terhadap biji kakao kering terfermentasi Lactobacillus plantarum HL 15. Skripsi Fakultas Teknologi Pertanian UGM, Yogyakarta. (2019).

25. Campos, J. Rodriguez, et al. 2011. Dynamics of Volatile and Non-volatile Compounds in Cocoa (Theobroma cacao L.) during Fermentation and Drying Process Using Principal Components Analysis. Food Research International 44 250-258.

26. Ho, Van Thi Thuy, et al. The Effect of Lactic Acid Bacteria on Cocoa Bean Fermentation. International Journal of Food Microbiology. 205, 54-67 (2015).

27. Esteve, E. P., Garcia, M. J. L., Fuentes, A., Palomares, C., \& Barat, J. M.: Control of Undeclared Flavoring of Cocoa Powders by the Determination of Vanillin and Ethyl Vanillin by HPLC. Food Control. 67, 171-176 (2016). doi:10.1016/j.foodcont.2016.02.048

28. Caligani, A., Marseglia, A., Prandi, B., Palla, G., and Sforza, S.: Influence of Fermentation Level and Geographic Origin on Cocoa Beans Oligopeptide Pattern. Food Chemistry. 211, 431-439 (2016). doi: 10.1016/j.foodchem.2016.05.072.

29. Brito, B. N. C., Chiste, R. C., Pena, S., Gloria, M. B. A., \& Lopes, A. S.: Bioactive Amines and Phenolic Compounds in Cocoa Beans Are Affected by Fermentation. Food Chemistry. 228, 484-490 (2017). doi:10.1016/j.foodchem.2018.02.004

30. Evina, V. J. E., Taeye, C., Niemenak, N., Youmbi, E., \& Colin, S.: Influence of Acetic and Lactic Acid on Cocoa Flavan-3-ol Degradation Through Fermentation-like Incubation. LWT Food Science and Technology. 68, 514-522 (2016). doi:10.1016/j/lwt.2015.12.047.

31. Camu, N., Winter, T., Addo, S. K., Takrama, J. S., Bernaert, H., \& L De Vuyzt: Fermentation of Cocoa Beans: Influence of Microbial Activities and Polyphenol Concentration on the Flavor of Chocolate. Journal of the Science of Food and Agriculture. 88(13), 2288-2297 (2008). doi:10.1002/jsfa.3349

32. Carillo, L. C., Londono, J. L., \& Gil, A.: Comparison of Polyphenol, Methylxanthines and Antioxidant Activity in Theobroma cacao Beans from Different Cocoa-growing Areas in Colombia. Food Research International. 60, 273-280 (2014). doi:10.1016/j.foodres.2013.03.019

33. Karisma, V L K. Pengaruh Penambahan Kultur Starter Lactobacillus plantarum HL15 pada Proses Fermentasi terhadap Biji Kakao (Theobroma cacao Linn.) yang Dikeringkan dengan Metode Sun Drying dan Artificial Drying. Skripsi. 2017. Fakultas Teknologi Pertanian Universitas Gadjah Mada Yogyakarta.

34. Russo, Pasquale, et al: Lactobacillus plantarum with Broad Antifungal Activity: A Promising Approach to Increase Safety and Shelf-life of Cereal-based Product. International Journal of Food Microbiology (2016).

35. Gerez, C. L., Torino, M. I., Obregozo, M. D., \& Valdez, F.: A Ready-to-use Antifungal Starter Culture Improves the Shelf Life of Packaged Bread. Journal of Food Protein. 73(4), 758-62 (2010). 